\title{
Nitrate Concentration in Drinking Groundwater Wells of Mekelle, Ethiopia (I)
}

\author{
Kelali Adhana Tekle ${ }^{1}$, Isao Yoshida ${ }^{2}$ and Masayoshi Harada ${ }^{3}$
}

\begin{abstract}
This paper examines the nitrate concentration in the Aynalem and Mekelle groundwater sources of drinking water for Mekelle city. A total of 15 water samples taken from the two well fields showed that significant differences in nitrate concentration. The lowest concentration $6.6 \mathrm{mg} / \mathrm{l}$ and highest concentration $46.8 \mathrm{mg} / \mathrm{l} \mathrm{were}$ found in the Aynalem groundwater wells. The highest nitrate concentration among the 10 wells of Aynalem was found downstream of the well field in an animal feedlot. On the other hand, with exception of one, Mekelle well located upstream from the main area of the city with a level of $11.7 \mathrm{mg} / \mathrm{l}$, the downstream wells contained concentrations of $54.6,65.7$, 97.5 , and $209 \mathrm{mg} / \mathrm{l}$. These samples exceed the maximum nitrate level of $50 \mathrm{mg} / 1$ for drinking water, a guideline set by the World Health Organization (WHO, 1996). Such anthropogenic sources as animal feedlots and municipal wastes are considered possible sources for the high concentration of nitrates in the Mekelle wells. Further study is needed to identify the sources of nitrate pollution in both groundwater well fields concentrating on geology, precipitation, land topology, soil profile, and its health impact on users.
\end{abstract}

Keywords: Mekelle; Water quality; Nitrate; Pollution; Methaemoglobinaemia

\section{Introduction}

In 2000, the Ethiopian Water Resources Management Policy was ratified, which emphasized on clean drinking water and sanitation. Government and non-government organizations tried to increase the supply of drinking water to both rural and urban areas. Groundwater wells were dug in promising sites to satisfy the ever-growing demand in urban areas. However, the demand in the cities for more water overshadowed concerns about water quality. A variety of causes impacted the water supply: uncontrolled population growth and migration from rural to urban area, the unavailability of adequate infrastructure and ineffective waste management regulations. Studies conducted in Addis Ababa, the capital of Ethiopia, showed that $80 \%$ of its factories discharge untreated effluents directly into nearby water sources. The city's municipal wastes are also poorly managed, causing severe water pollution problems (T.H. Consulting Engineers, 2000).

The city of Mekelle in Tigray, one of the regional states of the Federal Democratic Republic of Ethiopia, suffers from similar waste management problems. Municipal wastes (both liquid and solid) are dumped into the city's open fields, a practice unsafe to humans, the city's groundwater sources, and the environment. On the other hand, residents expect their city to be clean and free of human induced pollution. They have only a slight awareness of the depth of the problem of water pollution; they are unaware of its connections to the generation, collection, and disposal of waste; and they do not recognize how inadequate infrastructure contributes to the escalating problem.

The inhabitants of Mekelle depend entirely $(100 \%)$ on

'Postgraduate, Graduate School of Agriculture, Tottori University, Minami 4-101 Koyama-cho, Tottori, 680-8553 Japan

${ }^{2}$ Professor, Faculty of Agriculture, Tottori University, Minami 4-101, Koyama-cho, Tottori, 680-8553 Japan

Assistant Professor, Faculty of Agriculture, Tottori University, Minami 4-101, Koyama-cho, Tottori, 680-8553 Japan groundwater sources for their drinking water. Aynalem and Mekelle are the two groundwater sources that have been supplying drinking water for more than two decades. The Aynalem well field, located about 6 kilometers southeast of Mekelle at an average elevation of 2200 meters above sea level, has also been serving as farmland and animal feedlot. The small town of Aynalem, which the well field's name is derived from, is located in the area of the well field. The wells of Aynalem are pumped and conveyed through pipeline to Mekelle city while Aynalem town gets its water through on spot distribution.

Since 1994, farmers have been using such fertilizers as Urea and DAP (Di-Ammonium Phosphate) on their farmland, which will be a potential concern for groundwater's quality.

The Mekelle well field is located inside the city, which is at an average elevation of 2050 meters above sea level. Most of its wells are in a downstream area of the main part of the city, and drain to the west. The city has no adequate sewerage and storm drainage facilities, which aggravate its sanitation problem. During the rainy season, groundwater wells are polluted by waste that is washed into them.

Groundwater pollution sources are linked to land use and development activities. Urban development works, which are underway, will also generate more waste. Thus, the apparent relationship between the daily generation of waste and the use and development of urban land seems likely to increase the contamination of groundwater by nitrates. And yet, waste management practices have not improved. At present, the city's groundwater wells are at risk for nitrate pollution.

The objectives of this study are: (1) to determine the nitrate concentration in the two groundwater well fields, and (2) to propose possible solutions based on the findings. 


\section{Material and Methods}

In February 1997, 15 water samples (10 from Aynalem and 5 from Mekelle) were collected from Figure 1 in 1 liter polyethylene plastic bottles. Each well was pumped for about 3 to 5 minutes before sampling to insure that each sample was representative; the bottles were thoroughly rinsed with the water to be sampled, and a $\mathrm{pH}$ and electrical conductivity readings were recorded at each sampling point. The samples were labeled, sealed, and promptly transferred to the Water Quality Control Regional Laboratory under the auspices of Tigray National Regional State Water Resources Development, Mines and Energy Bureau. They were analyzed immediately at the laboratory to avoid deterioration. A Spectrophotometer (HACH DR/2000) was used to analyze the nitrates. The standard Methods of AWWA APHA WPCF (1989) were used to determine the following values: $\mathrm{pH}$, electrical conductivity (EC), total dissolved solids (TDS), total hardness (TH), total alkalinity (TA), Calcium $\left(\mathrm{Ca}^{2+}\right)$, Magnesium $\left(\mathrm{Mg}^{2+}\right)$, Sodium $\left(\mathrm{Na}^{+}\right)$, Potassium $\left(\mathrm{K}^{+}\right)$, Bicarbonate $\left(\mathrm{HCO}_{3}{ }^{-}\right)$, Sulfate $\left(\mathrm{SO}_{4}{ }^{2-}\right)$, Chloride $\left(\mathrm{Cl}^{-}\right)$, Nitrate $\left(\mathrm{NO}_{3}{ }^{-}\right)$, and Nitrite $\left(\mathrm{NO}_{2}^{-}\right)$. Except for $\mathrm{pH}$, and $\mathrm{EC}$ in $\mu \mathrm{S} / \mathrm{cm}$ (micro-siemens per centimeter) all parameter values are expressed in $\mathrm{mg} / \mathrm{l}$ (milligram per liter) .

\section{Results and Discussion}

\subsection{Water quality}

Water quality analyses results of Aynalem and Mekelle groundwater wells are presented in Table 1. As shown in the table, the nitrate concentrations of the Aynalem groundwater wells were below the recommended guidelines for drinking water (WHO, 1996). Two wells, AW5 and AW9, located downstream of the well field in an animal feedlot, contained higher concentrations of nitrate, 46.8 $\mathrm{mg} / \mathrm{l}$ and $44.3 \mathrm{mg} / \mathrm{l}$, respectively, compared to the other

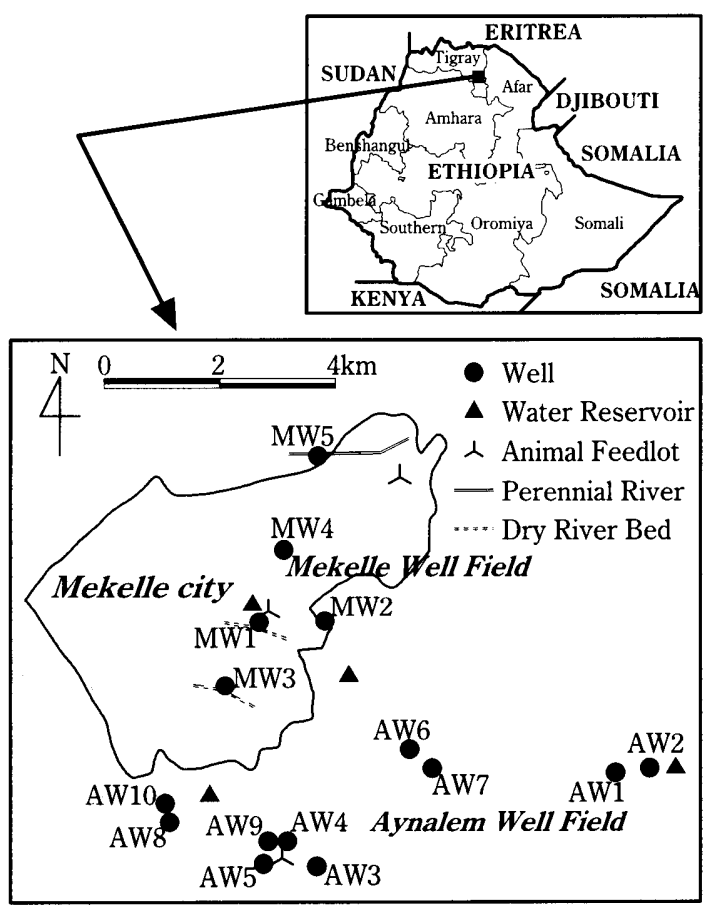

Figure 1: Map of the study area eight wells.

Four of the five Mekelle wells that were analyzed contained nitrate levels that ranged from 54.6 to $209 \mathrm{mg} / \mathrm{l}$. They are located in the city but not concentrated in one area. MW1, which had a nitrate level of $65.7 \mathrm{mg} / \mathrm{l}$, is located along a small dry riverbed that receives waste drainoff from municipal holding sites. The surrounding area has also been used as an animal feedlot. Similarly, MW3, which had a nitrate level of $209 \mathrm{mg} / \mathrm{l}$, is located inside the city near a dry riverbed where liquid and solid wastes have been unsafely disposed, ignoring the potential impact on the environment. MW4 with nitrate level $54.6 \mathrm{mg} / 1$ is located inside a car maintenance compound. MW5 with a nitrate level of 97.5 $\mathrm{mg} / \mathrm{l}$ is located far from the center of the city, close to an animal feedlot and the Perennial River. Unlike the other four wells, MW2 with a low nitrate concentration of 11.7 $\mathrm{mg} / \mathrm{l}$ is located upstream of the main city.

The results of higher concentrations of nitrates in Mekelle wells reflect a considerable deterioration in quality of the groundwater wells that are located downstream from the main city. Human-created sources of pollution are the possible source for such high levels in the four wells because they were located along nitrate generating sources. In Argentina, a similar study of rural and urban areas found concentrations of nitrate as high as $240 \mathrm{mg} / \mathrm{l}$; it attributed such levels in the city ground water wells to human actions (Usunoff and Varni, 1995). Another study of such groundwater sources as wells, boreholes, and springs conducted from July 1997 to July 2000 in a region of southern Portugal called Alentejo found maximum nitrate concentrations that ranged from 126 to $225 \mathrm{mg} / \mathrm{l}$. It blamed agricultural pollution. This region depends heavily on its groundwater resources for public drinking water as well as for agricultural uses (Paralta and Ribeiro, 2001).

The Mekelle study area does not have adequate sewerage system, which is another likely explanation for its groundwater wells containing higher levels of nitrate than those in rural Aynalem, and the groundwater well field has been serving as water supply source for the city for more than 20 years.

A comparison of the $\mathrm{pH}$ values of the samples taken from the well fields shows only an insignificant difference. The $\mathrm{pH}$ values of the samples from Aynalem ranged from 7.1 to 7.9 with an average 7.32 , and the $\mathrm{pH}$ values of the Mekelle samples ranged from 6.8 to 7.4 with an average of 7.16. Similarly, the total alkalinity (TA) values of the two well fields did not show much variation. However, in addition to the presence of nitrates, the Mekelle samples also contained high values of EC, TDS, TH, $\mathrm{Ca}^{2+}, \mathrm{Na}^{+}, \mathrm{Cl}^{-}$and $\mathrm{SO}_{4}{ }^{2-}$. The analysis of the samples indicated that the Aynalem wells are less polluted than the Mekelle wells.

The results of the major cations and anions of the two well fields are plotted on a trilinear diagram based on their milliequivalent per liter percentage composition to reveal the characteristic dominancy of major ions Figures 2 and 3.

Samples that had similar water quality are plotted together. The circles, in the diamond-shaped area, circumscribed the corresponding well numbers indicate an area proportional to the total dissolved solids, and the radii scale 
Table 1: Water quality analyses results of Aynalem and Mekelle groundwater wells

AYNALEM

\begin{tabular}{cccccccccccccccc}
\hline $\begin{array}{l}\text { Well } \\
\text { No. }\end{array}$ & $\begin{array}{c}\text { Main } \\
\text { aquifer }\end{array}$ & $\mathrm{pH}$ & $\mathrm{EC}$ & $\mathrm{TDS}$ & $\mathrm{TH}$ & $\mathrm{TA}$ & $\mathrm{Ca}^{2+}$ & $\mathrm{Mg}^{2+}$ & $\mathrm{Na}^{+}$ & $\mathrm{K}^{+}$ & $\begin{array}{c}\mathrm{HCO}_{3} \\
-\end{array}$ & $\mathrm{Cl}^{-}$ & $\mathrm{SO}_{4}{ }^{2-}$ & $\mathrm{NO}_{3}^{-}$ & $\mathrm{NO}_{2}^{-}$ \\
\hline AW1 & LS & 7.1 & 610 & 330 & 257 & 218 & 82 & 12 & 69 & 12 & 266 & 35 & 125 & 39.6 & - \\
AW2 & LS & 7.2 & 685 & 380 & 363 & 247 & 128 & 10 & 28 & 2 & 301 & 30 & 125 & 22.9 & - \\
AW3 & LS & 7.2 & 750 & 420 & 440 & 244 & 124 & 31 & 54 & 2 & 298 & 18 & 285 & 8.3 & 0.01 \\
AW4 & D & 7.2 & 835 & 460 & 460 & 250 & 160 & 14 & 58 & 15 & 305 & 20 & 315 & 14.1 & 0.05 \\
AW5 & D & 7.3 & 1085 & 600 & 650 & 210 & 208 & 31 & 75 & 13 & 256 & 18 & 575 & 46.8 & 0.42 \\
AW6 & LS & 7.1 & 720 & 400 & 390 & 340 & 140 & 10 & 92 & 13 & 415 & 20 & 238 & 19.7 & 0.17 \\
AW7 & LS & 7.2 & 780 & 440 & 510 & 300 & 168 & 22 & 135 & 12 & 366 & 240 & 200 & 13.7 & 0.17 \\
AW8 & LSD & 7.9 & 1200 & 746 & 585 & 250 & 180 & 32 & 70 & 15 & 305 & 85 & 375 & 17.2 & 0.07 \\
AW9 & LSD & 7.2 & 900 & 547 & 385 & 340 & 144 & 6 & 69 & 12 & 427 & 35 & 140 & 44.3 & 0.62 \\
AW10 & LSD & 7.8 & 780 & 460 & 480 & 150 & 144 & 29 & 20 & 1 & 183 & 50 & 325 & 6.6 & 0.26 \\
\hline
\end{tabular}

MEKELLE

\begin{tabular}{lccccccccccccccc}
\hline $\begin{array}{l}\text { Well } \\
\text { No. }\end{array}$ & $\begin{array}{c}\text { Main } \\
\text { aquifer }\end{array}$ & $\mathrm{pH}$ & $\mathrm{EC}$ & $\mathrm{TDS}$ & $\mathrm{TH}$ & $\mathrm{TA}$ & $\mathrm{Ca}^{2+}$ & $\mathrm{Mg}^{2+}$ & $\mathrm{Na}^{+}$ & $\mathrm{K}^{+}$ & $\begin{array}{c}\mathrm{HCO}_{3} \\
\mathrm{Cl}^{-}\end{array}$ & $\mathrm{SO}_{4}{ }^{2-}$ & $\mathrm{NO}_{3}^{-}$ & $\mathrm{NO}_{2}^{-}$ \\
\hline MW1 & LSS & 7.3 & 2100 & 1170 & 1010 & 212 & 372 & 19 & 135 & 5 & 259 & 225 & 775 & 65.7 & 0.14 \\
MW2 & LS & 7.4 & 2220 & 1280 & 1410 & 178 & 400 & 98 & 47 & 11 & 217 & 55 & 1300 & 11.7 & 0.08 \\
MW3 & LS & 6.8 & 2990 & 1660 & 1350 & 260 & 492 & 28 & 370 & 70 & 317 & 420 & 1225 & 209 & 0.41 \\
MW4 & LS & 7.2 & 1765 & 1080 & 1530 & 212 & 456 & 94 & 110 & 25 & 259 & 270 & 1175 & 54.6 & 0.03 \\
MW5 & LS & 7.1 & 2460 & 1410 & 1220 & 256 & 468 & 25 & 310 & 65 & 312 & 135 & 1550 & 97.5 & 0.03 \\
\hline
\end{tabular}

LS: Limestone, D: Dolerite, LSD: Limestone and Dolerite, LSS: Limestone and Shale

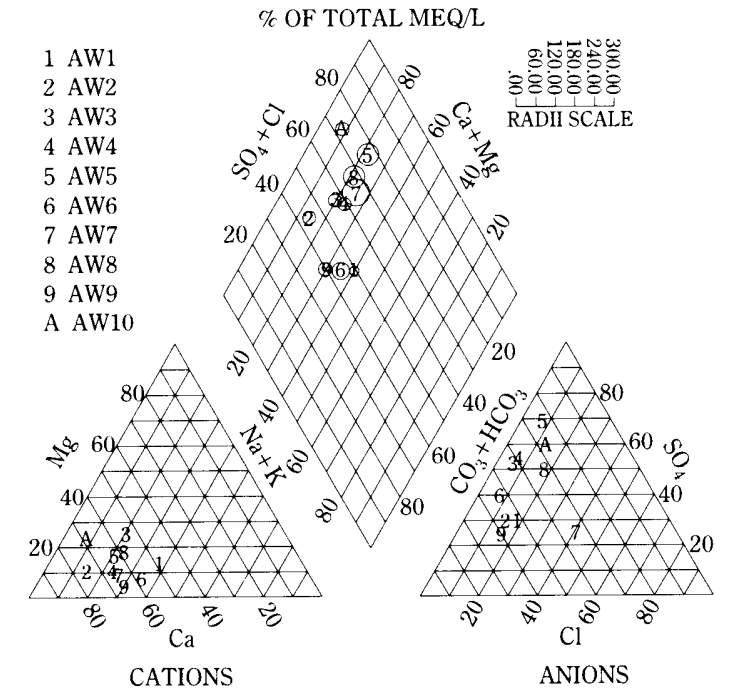

Figure 2: Trilinear diagram representing analyses of Aynalem Groundwater wells

is in $\mathrm{mg} / \mathrm{l}$. In both well fields, calcium was the dominant ion from the major cations group. Ground waters from both well fields (Aynalem and Mekelle) are of the $\mathrm{Ca}-\mathrm{SO}_{4}-\mathrm{Cl}$ type. After the analysis, the ionic balance of the major cations and anions were computed, and it was found in the range of 0.93 to 1.07 , and 0.94 to 1.06 for Aynalem and Mekelle respectively. The laboratory analysis error percentage was found less than 5\%; for the Aynalem wells it ranged from 1.07 to 3.55 , averaging 1.91; the Mekelle wells ranged from 1.22 to 3.00 , averaging 2.27 .

\subsection{Sources of nitrate and pollution}

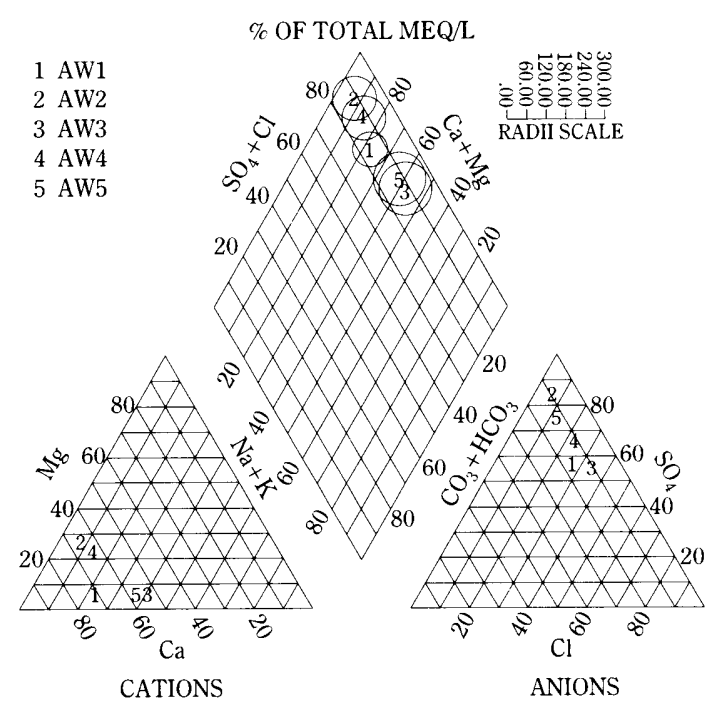

Figure 3: Trilinear Diagram representing analyses of Mekelle Groundwater wells

Low concentrations of nitrates in groundwater and surface water are natural. Sedimentary rocks contribute major portion of the soluble constituents to groundwater because they are highly soluble and abundant in the earth's crust $\mathrm{Ca}^{+}$ and $\mathrm{Ca}^{2+}$ are the commonly added cations, and $\mathrm{HCO}_{3}{ }^{-}$and $\mathrm{SO}_{4}{ }^{2-}$ are the corresponding anions). However, a high presence of nitrates in ground water indicates pollution, and most pollution originates from disposal of wastes after water has been used for wide range of purposes (Todd, 1980). The high nitrate concentration in drinking water is also closely related to anthropogenic sources as runoff from agricultural activities, the poor treatment of wastes, and 
disposal of both human and animal excreta. These nitrate sources, which are generated by nonpoint source, will gradually decompose to ammonia, and then the ammonia stepwise oxidized in the soil by bacterial action to nitrate. Nitrate, the stable form of nitrogen oxide, is very soluble in water. Plants extract it from the soil because it is an essential element for their growth. Surplus will be leached into the groundwater through percolation. Surplus nitrates infiltrate the subsurface at rates that depend on precipitation, geology, and the texture of the soil's profile. As little rainfall as $13 \mathrm{~mm}$ can induce runoff from a cattle feedlot (Ritter and Shirmohammadi, 2000).

The average maximum daily rainfall in the study area for the months of July and August from 1995 to 2000 was 33.5 $\mathrm{mm}$, Figure 4, more than enough to induce runoff.

The animal feedlot in the Aynalem well field could be the possible source for the relatively higher amounts of nitrate concentration in the waters AW5 and AW9 as compared to the other eight wells, which are located upstream of the animal feedlot. The feedlot has existed for many decades even before the construction of the wells. The fertilizers effect was not observed in the water quality analyses since it has been started three years before the study was conducted. However, fertilizer application on the Aynalem well field would be future threat for the groundwater wells because fertilizers in addition to animal feedlot are main sources of nitrate pollution in groundwater wells (Botkin and Killer, 1997).

Nitrate pollution in municipal drinking water can also occur because of seepage from manure storage basins and lagoons, disposal pits for dead animals, stockpiled manure, and livestock feedlots (Ritter and Shirmohammadi, 2001). Masters (1991) also stated that high levels of nitrogen in municipal water supplies indicate runoff from animal feedlots. These studies show that groundwater sources near by agricultural activities and municipal waste disposal sites are more susceptible to nitrate pollution, and these anthropogenic sources occur sporadically in nature, varying both temporally and spatially based on rainfall. Nitrate pollution is classified as diffuse or non-point source, which is difficult to monitor because it can vary by season. The source for the high level of nitrate concentration in the Mekelle wells could be the unsafe disposal of municipal wastes, the inadequacy of sewerage systems, or runoff from the animal feedlots since the nitrate contaminated wells are located

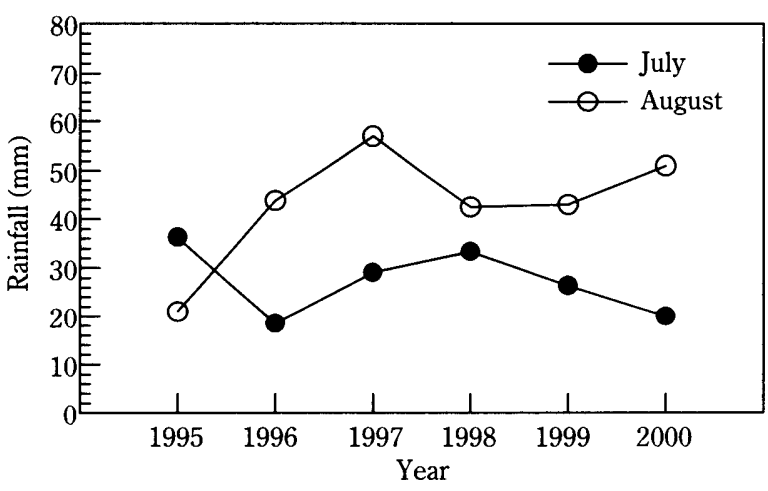

Figure 4: Maximum daily rainfall pattern of the study area in July and August (1995-2000) along and downstream of nitrate generating sources.

\subsection{Methaemoglobinaemia}

Methaemoglobinaemia, a disease caused by inability of the blood to carry oxygen throughout the body, has been associated with nitrates in the drinking water since 1945 (Camp and Donahue, 1994). Nitrates are toxic because they are reduced to toxic nitrites by bacterial action, especially in the stomachs of infants. Nitrites then convert hemoglobin in the blood to methaemoglobin, reducing the ability of hemoglobin to carry oxygen throughout the body. The result is oxygen starvation that causes a bluish discoloration of infants, commonly described as the "blue baby syndrome" (Masters, 1991)

According to WHO (1996), younger infants are more susceptible to methaemoglobinaemia than older children and adults. One possible explanation may be that the large proportion of fetal hemoglobin in the blood of these infants is more easily oxidized to methaemoglobin. Older people may also be at risk because their body secretes less gastric acid; cases of methaemoglobinaemia are also linked to malnutrition and infection, increasing the risks in developing countries where drinking water is often obtained from shallow wells.

In the study area, health records were not available; however, we can assume that health risks exist, since $26.7 \%$ of the wells contained levels of nitrate that exceed the safety guideline value of $50 \mathrm{mg} / \mathrm{l}$. To protect bottlefed infants from the possible effects of nitrate, the level of nitrates in drinking water should not exceed the guideline value. Due to the simultaneous occurrences of nitrites and nitrates in drinking water, then the sum of their ratios of concentration $(\mathrm{C})$ to guideline value $(\mathrm{GV})$ should not exceed 1:

$$
\frac{C_{\text {nitrite }}}{G V_{\text {nitrite }}}+\frac{C_{\text {nitrate }}}{G V_{\text {nitrate }}} \leq 1
$$

Based on (1) (WHO, 1996), the four wells in Mekelle had values of $1.10,1.36,1.96$, and 4.32 , revealing the water is not potable. In both well fields, nitrite concentrations were below the guideline value of nitrite, 3mg/l (WHO, 1996).

\section{Proposed Management Actions}

Based on the analytical findings and prevailing scenarios on both groundwater well fields, the following management actions should be taken into consideration.

(1) Developing appropriate waste management practices for the city that comprehensively addresses potential pollutant sources of nitrate; parallel with this, promotion of public awareness towards safe disposal of wastes should be strengthened, and these should be well tailored to Mekelle's condition.

(2) Delineating Aynalem well field from human induced pollutions since the groundwater quality of Anynalem is by far better than Mekelle well field and is the prospective source for the city. 
(3) Water quality monitoring should be carried out on regular basis to ensure the quality of supplied water to the residences.

\section{Conclusions}

Groundwater is the main source for Mekelle's drinking water supply, and four of its wells contained levels of nitrate greater than the safety guideline value of $50 \mathrm{mg} / \mathrm{l}$. High nitrate levels in drinking water are associated with methaemoglobinaemia in bottlefed infants. Thus, a more detailed study should investigate the health impact of nitrate on users; it should also further identify the sources of pollution in both of these groundwater well fields, concentrating on geology, land topology, soil profile, and precipitation.

\section{References}

[1] APHA-AWWA-WPCF. (1989): Standard methods for the examination of water and wastewater, 17th edition, APHA, AWWA, APCF.

[2] Botkin, D. B., and Killer, E. A. (1997): Environmental science Earth as a living Planet, 2nd edition, John Wiley and Sons, pp.416-422.

[3] Camp, W. G., and Donahue, R. L. (1994): Environmental science for agriculture and the life science, Delwar publishers, pp.145-147.

[4] Masters, G. M. (1991): Introduction to environmental en- gineering and science, Prentice Hall, pp.110-111.

[5] Paralta, E., and Ribeiro, L. (2001): Stochastic modeling and risk maps of nitrate pollution in the vicinity of Beja, Alentejo, south Portugal, Proceeding of $3 r d$ International Conference on FUTURE GROUNDWATER RESOURCES AT RISK, pp. 251-261.

[6] Ritter, W. F., and Shirmohammadi, A. (2001): Agricultural non-point source Pollution, Watershed Management and Hydrology, Lewis Publishers, pp.1-7, 68-80, 142-161.

[7] T. H. Consulting Engineers. (2000): Final report on strategy and implementation plan for environmental monitoring water resources in Addis Ababa; Pollution control strategy and implementation plan, Addis Ababa Water and Sewerage Authority, pp.23-52.

[8] T. H. Consulting Engineers. (2000): Final report on strategy and implementation plan for environmental monitoring water resources in Addis Ababa; Study of existing situations, Addis Ababa Water and Sewerage Authority, pp.18-32.

[9] Todd, D. K. (1980): Groundwater Hydrology, 2nd edition, John Wiley and Sons, pp.270-292, 316-317.

[10] Usunoff, E. J., and Vari, M. R. (1995): Nitrate polluted groundwater of Azul, Argentina: characterization and management issues, Journal of Environmental hydrology, $\mathbf{3}$ (2), 1-7.

[11] WHO. (1996): Guideline for drinking water quality 2nd edition, volume 2 health criteria, and other supporting information, World Health Organization.

Discussion open until June 30, 2005 